I.M. Guseva ${ }^{1}$, T.E. Borovik ${ }^{1,2}$, A.V. Surzhik ${ }^{1}$, L.S. Namazova-Baranova ${ }^{1,2,3}$, I.N. Zakharova ${ }^{4}$, N.G. Zvonkova ${ }^{1,2}$, N.N. Semyonova ${ }^{1}$, O.L. Lukoyanova ${ }^{1}$, T.V. Bushuyeva ${ }^{1}$, T.N. Stepanova ${ }^{1}$

${ }^{1}$ Scientific Center of Children's Health, Moscow, Russian Federation

${ }^{2}$ Sechenov First Moscow State Medical University, Russian Federation

${ }^{3}$ Pirogov Russian National Medical Research University, Moscow, Russian Federation

${ }^{4}$ Russian Medical Academy of Postgraduate Education, Moscow, Russian Federation

\title{
Description of diets of the 12-36-month-old children residing in Moscow
}

\section{Author Affiliation:}

Tatyana Edwardovna Borovik, MD, PhD, Professor, head of the pediatric nutrition department at the Scientific Center of Children's Health

Address: 2/1 Lomonosovskiy Av., Moscow, 119991; tel.: +7 (499) 132-26-00; e-mail: borovik@,nczd.ru

\section{Article received: 23.08.2014. Accepted for publication: 17.09.2014.}

Significance. Imbalanced diet in early childhood often results in medical issues, including mental retardation, impaired adaptation mechanisms and worsened immunological protection. The amount of studies, which could help to assess dietary peculiarities of 1-3-year-old children living in a Russian megalopolis and reveal probable deficiencies of the essential macro- and micronutrients, as well as the prevalence of eating behavior disorders. The study was aimed at assessing the nature and peculiarities of the diet of the 12-35-month-old children residing in Moscow. Patients and methods. 106 1-3-year-old children were examined at two pediatric polyclinics in Moscow; they were divided into two groups: I -12-23-month-old children, II - 24-35-month-old children. Results. The authors performed a comprehensive analysis of actual diets of young children, including assessment of the nature of consumed foods and dishes, as well as of nutritional value of daily rations. Conclusions. The authors established that diets of most 1-3-year-old children residing in the megalopolis conform to the current criteria. Excessive consumption of high-protein foods, insufficient consumption of specialized functional foods, early introduction of "adult foods" and non-observance of the dietary pattern were observed in several cases.

Keywords: 12-35-month-old children, actual diets, daily ration, proteins, fats, carbohydrates, caloric content, specialized foods, dietary pattern.

\section{INTRODUCTION}

A balanced diet is one of the main components of human health. Nowadays the issues of rational preventive and therapeutic diet for infants of the first year as the most important period of childhood is well developed and described in detail in scientific publications. However, at the age of 1 to 3 years the rates of growth and development of all the organs and systems of the child remain high, which is the reason for the issue of adequately constructing the diet of children older than 1 year being crucial and difficult at the same time for both parents and doctors.

An irrational diet, not adapted to the needs of children of this age often leads to chronic deficiency of essential nutrients, which in its turn could have a negative impact on their intellectual development and resistance to adverse infectious and environmental factors [1,2].

It is found that children who suffer from iron deficiency anemia, have not only delayed formation of cognitive function and lower rates of psychomotor development in the first years of life, but also a decreased ability to and focus at school age $[2,3]$. The lack of adequate iodine consumption hinders the functioning of the thyroid gland and immune system and drastically affects the psychological development of children $[4,5]$. Deficiency of $\omega-3$ polyunsaturated fatty acids affects the formation 
of the brain, visual functions, immunity [6]. It has been established that even mild cases of vitamin D deficiency often lead to disorders of bone tissue that may develop in adulthood [7].

Studies in several European countries and Russia have demonstrated a significant deficit of macroand micronutrients in the diets of children older than 1 year [8-10].

There is growing scientific evidence that inadequate nutrition in early childhood poses a risk for the development of diseases in adulthood. The consequences of conditions associated with nutritional disorders may be delayed and have a negative impact on human physical development and intellectual potential [11-13]. A number of studies carried out in recent years have shown that the foundation for arterial hypertension and atherosclerotic changes, obesity and diabetes widespread in the adult population is laid in early childhood [14-16].

The incidence of nutrition-related diseases among children in Russia remains very high [17, 18]. For example, in recent years the problem of excess weight and obesity in children of all age groups has acquired a great social significance [19-21].

Given the importance of a balanced diet and its influence on the formation of all the functions and structures of the body, as well as preserving the health of infants, epidemiological observational studies are conducted that allow a comprehensive assessment of the features and characteristics of children's nutrition [22-25] and, if necessary, a timely correction of the diet.

In Russia, to date there has been little research summarizing data on the nutritional habits of infants living in metropolis conditions, as well as the major macro- and micronutrients deficits and the incidence of eating disorders.

Objective: study the nature and characteristics of nutritional habits of children aged 12-36 months living in Moscow.

\section{PATIENTS AND METHODS}

\section{Participants of the study}

The work was conducted as part of the All-Russian inter-regional epidemiological multicentre study of nutritional habits of children aged 1-3 years under the supervision of the Scientific Center for Children's Health and the Russian Medical Academy of Postgraduate Education, with the support of "Nutricia" (Istra, Moscow region). The study has been approved by the Interdisciplinary Ethics Committee in writing.

The study involved 106 tentatively healthy children aged 1 to 3 years, living in Moscow. The sample of children examined during the study was chosen at random.

Selection criteria:

- Full-term infants of both sexes aged 12-36 months with birth weight of 2500-4500 g;

- An informed voluntary consent to participate signed by the child's parent/legal representative

The study excluded children following special diets because of pronounced manifestations of food allergy, lactase deficiency, metabolic disorders, as well as those with severe chronic diseases that could affect appetite and digestive function (neurological diseases, cystic fibrosis, celiac disease, etc).

Depending on age, all the children were divided into two groups:

Group I: 59 children (25 boys, 34 girls) aged 12-23 months (mean age $17.76 \pm 3.2$ months);

Group II: 47 children (24 boys, 23 girls) aged 24-35 months (mean age 29.64 \pm 3.1 months).

\section{Research methods}

To obtain evidence, the questionnaire method was used.

The first section of the survey was a questionnaire that takes into account family history data (social status, parents' education, number of children in the family, which child in succession that is, a subjective assessment of the child's diet by a parent, the peculiarities of the family diet). The records included data on the duration of breastfeeding, age at introduction of supplemental food and the type 
of supplemental food, the frequency of introduction of traditional natural products (whole cow milk and dairy products, vegetables, fruit, meat, fish), "adult" products (sausages, dumplings, seafood, fast food, sweets, soft drinks, etc.); as well as the amount of salt and sugar added during cooking. A lot of attention was given to the consumption of specific foods rich in macro- and micronutrients and intended for young children.

The information about pervious diseases (acute respiratory and intestinal infections, allergic diseases) was recorded.

The second section of the survey was a food diary filled out by a parent (or the caregiver of a child). The research method was a 3 -day diet ( 2 weekdays and 1 weekend) reconstruction.

\section{Statistical processing of data}

The statistical processing of the results of the study was carried out using the standard methods of variation statistics with the help of SPSS / PASW Statisticus version 18 (SPSS Inc., Illinois, Chicago, USA).

The nutritional value of the diet was determined using Dietplan 6 (Forestfield Software Ltd., UK). The program allows calculating the daily intake of nutrients with respect to various factors (such as age, sex, weight, physical activity, etc.) and comprises nutrient intake norms and energy value of food products recommended as of 1991 By COMA, the Committee of Medical Aspects of Food and Nutrition Policy. The program is adapted to the nutritional norms and standards of the Russian Federation (2008) [26-28].

\section{RESULTS}

\section{Evaluation of the children's medical history}

The analysis of medical history data revealed that almost all the children came from socially advantaged families. The majority of mothers $(75.5 \%)$ and fathers $(63.2 \%)$ had a higher education, and $5(4.7 \%)$ of the parents had an academic degree. 26 (24.5\%) mothers and $33(31.1 \%)$ fathers (Pic. 1) had secondary or vocational education. Three mothers continue their education in institutions of higher and professional education. At the time of the survey, $79(74.5 \%)$ mothers did not work, 65 of them (82\%) were on maternity leave and $14(18 \%)$ were housewives.

Pic. 1. The parents' education in the examined groups of children 


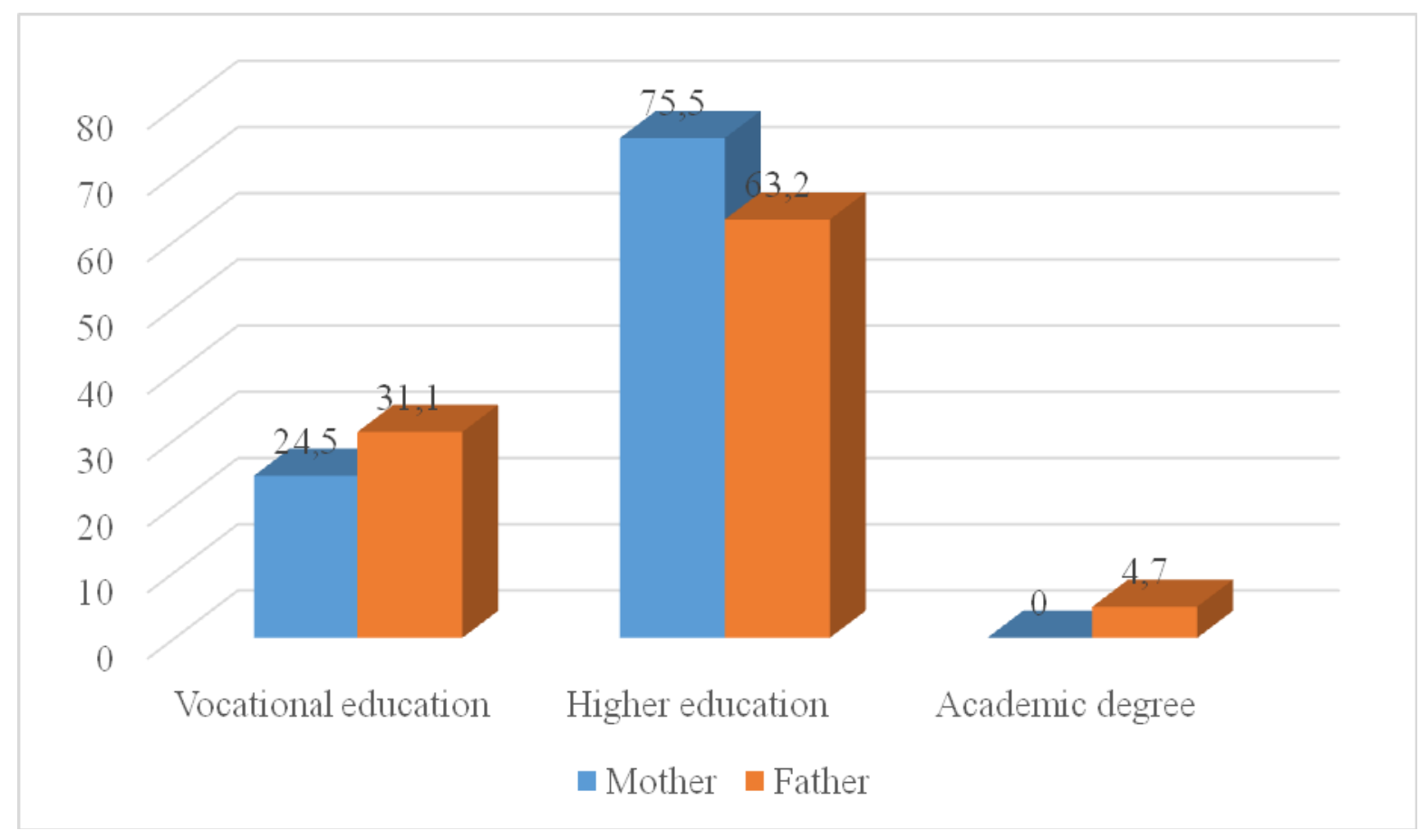

The analysis of family size showed that the majority (64 families; 60.4\%) had one child, 33 families $(31.1 \%)$ had two children; there were 9 large families (8.5\%): 8 families had three children, one family had four. The examined child was the first in 71 families (67\%), the second in $28(26.4 \%)$ and the third or fourth in 7 families $(6.6 \%)$.

The analysis of the allergic anamnesis showed that in 51 surveyed families $(48.1 \%)$ there was a history of allergic diseases (asthma, atopic dermatitis, food allergies, etc.) in the child's immediate family (mother, father, older siblings). According to the parents, short-term episodes of allergic reactions in the form of cheek hyperemia were observed in $71(66.9 \%)$ children and did not require treatment.

According to the survey, all of the observed children were breastfed in the first year of their life. For $32(30.2 \%)$ children, breastfeeding was stopped before 3 months of age, for $16(15.1 \%)$, it was in the range between 4 and 6 months, for $11(10.4 \%)$ children, in the range between 7 and 9 months, for 12 $(11.3 \%)$, between the months 10 and 12 . It should be noted that more than $1 / 3$ of the children were breastfed for over 12 months (Pic. 2).

Pic. 2. Duration of breastfeeding of the examined children $(n=106)$ 


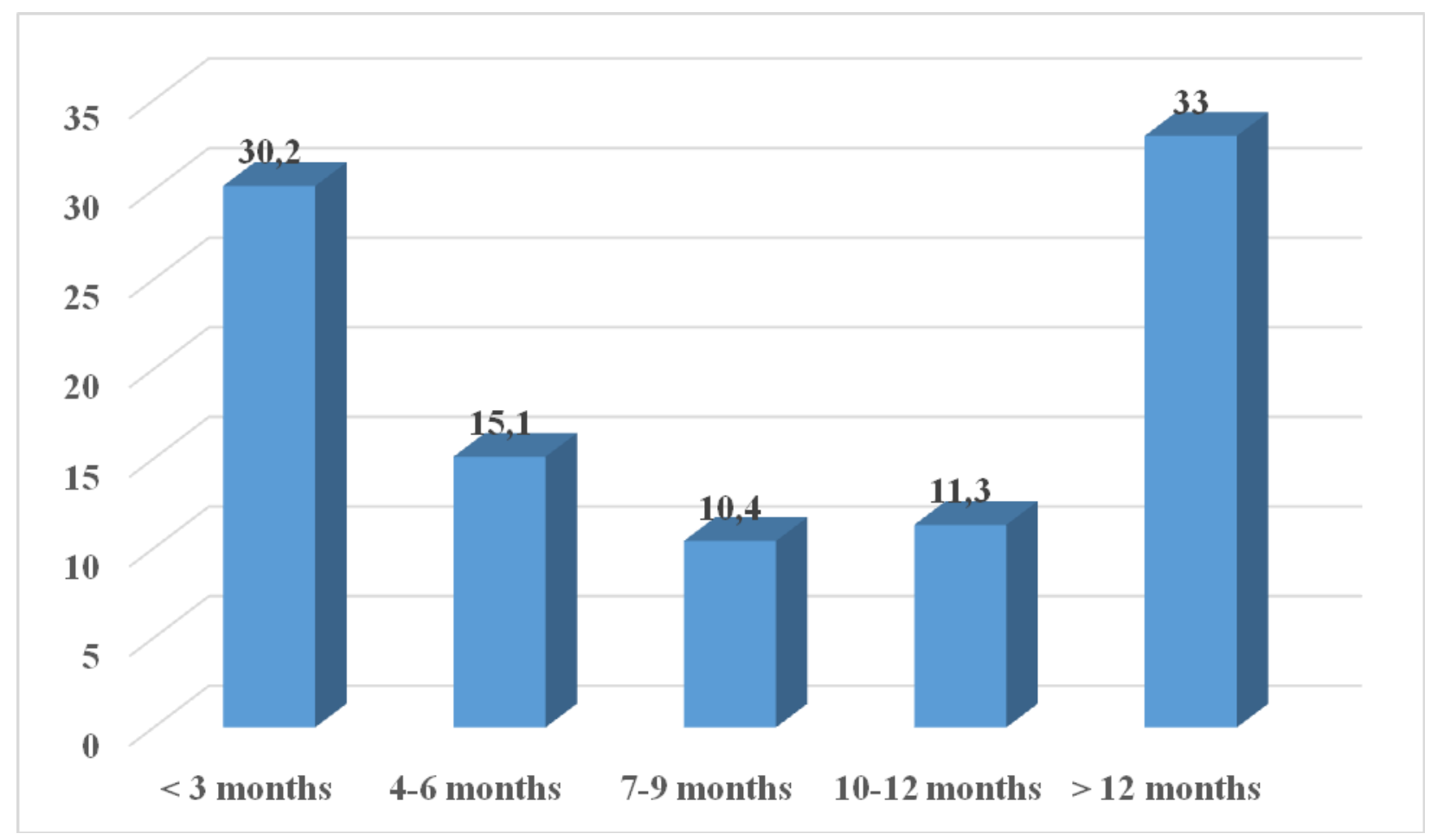

It was found that the average duration of breastfeeding was $8,9 \pm 6,8$ months, with no significant differences between the groups.

When analyzing the incidence of diseases it was noted that none of the examined children had chronic somatic diseases. However, during the first year of life, the majority (78 children; $74 \%$ ) suffered acute respiratory virus infections (ARVI) with varying frequency of occurrence: 47 children (44.3\%) had 1 to 2 cases, 20 children (18.9\%) - 3 to 4 cases, 11 children $(10.4 \%)$ had 5 or more cases of ARVI a year. It is important to emphasize that $28(26.4 \%)$ children had never suffered ARVI during the first year of life. A correlation of the frequency of ARVI and duration of breastfeeding has been established: the duration of breastfeeding in the absence of ARVI in the first year of life was $8.8 \pm 6.7$ months, with 1 to 2 cases of ARVI it was 9.6 \pm 7.6 months, with 3-4 cases it was $7.4 \pm 5.2$ months, with 5 or more cases it was $8.6 \pm 6.0$ months.

In the first year of life, acute intestinal infections episodes were observed in $23(21.7 \%)$ children. It was found that children without a history of acute intestinal infections in the first year were breastfed for a longer time $(9,2 \pm 6,7$ months) than those who have had the disease $(7,6 \pm 7,0$ months). However, these differences are statistically insignificant.

The study revealed a great variation of the age when supplemental food was introduced. 7 (6.6\%) children received supplemental food before 3 months of age, $32(30.2 \%)$ at 4 months, $30(28.3 \%)$ at 5 months, $28(26.4 \%)$ at 6 months, $9(8.5 \%)$ after 7 months of age, including 2 children who received first supplemental food after 12 months of age (Pic. 3).

Pic. 3. Age at introduction of supplemental food 


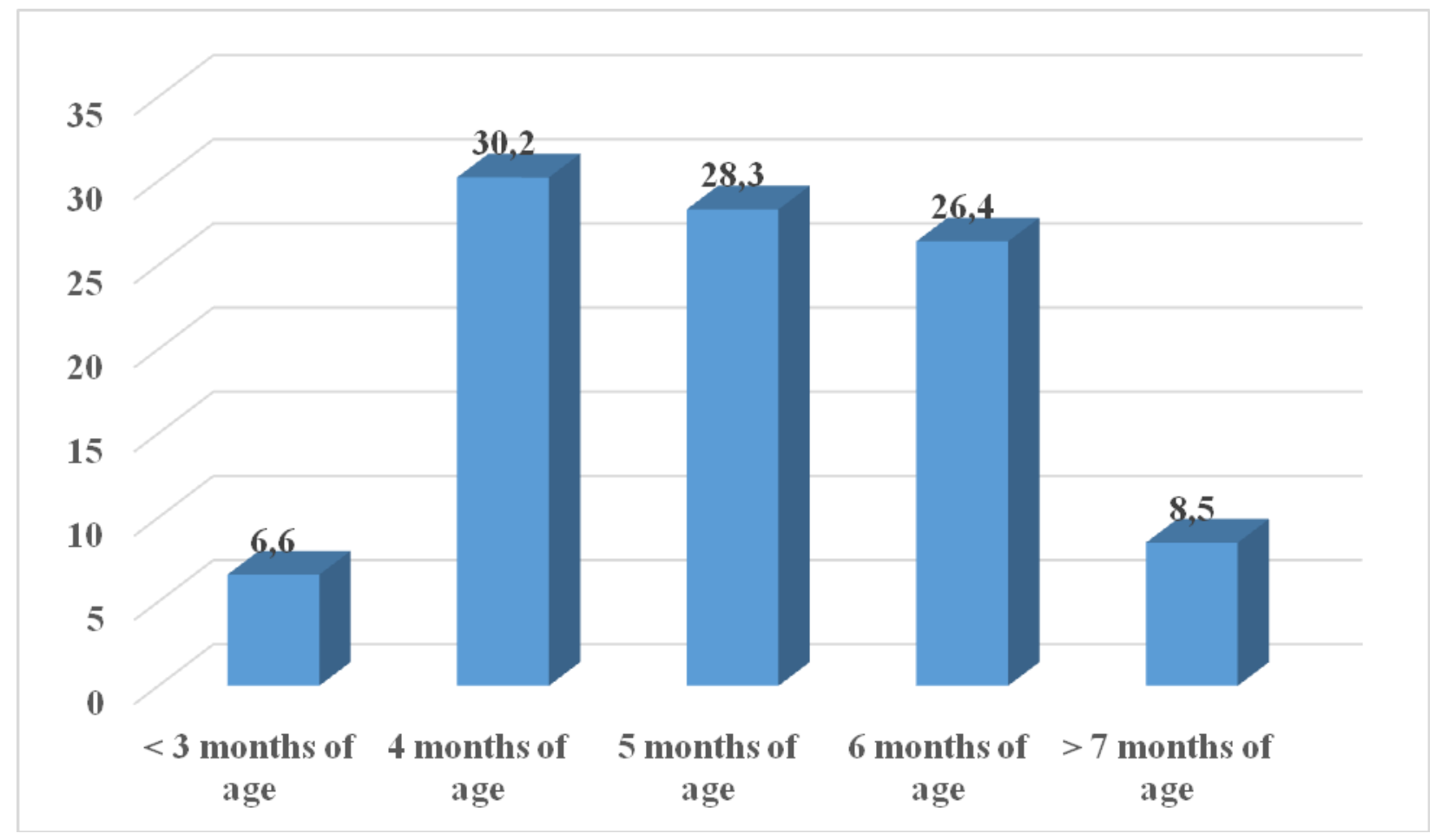

The National Program for optimization of infants' nutrition in the first year of life (2009) developed in the Russian Federation provides guidance on the introduction of supplemental foods indicating the need for his prescription in the range of 4 to 6 months (the so-called 'critical early window' of forming a food tolerance) [29]. During the study, it was found that the majority of children (84.9\%) received the supplemental food prescription in the aforementioned time. This fact indicates an active implementation of the document in pediatric practice.

The first supplemental food products (Pic. 4) for the majority (51 children; 48.1\%) included mashed vegetables, for $26(24.5 \%)$, it was mashed fruit, 21 children $(19.8 \%)$ received porridge, 8 children (7.6\%) - other products (juices, cottage cheese). 
Pic. 4. The first supplemental food products

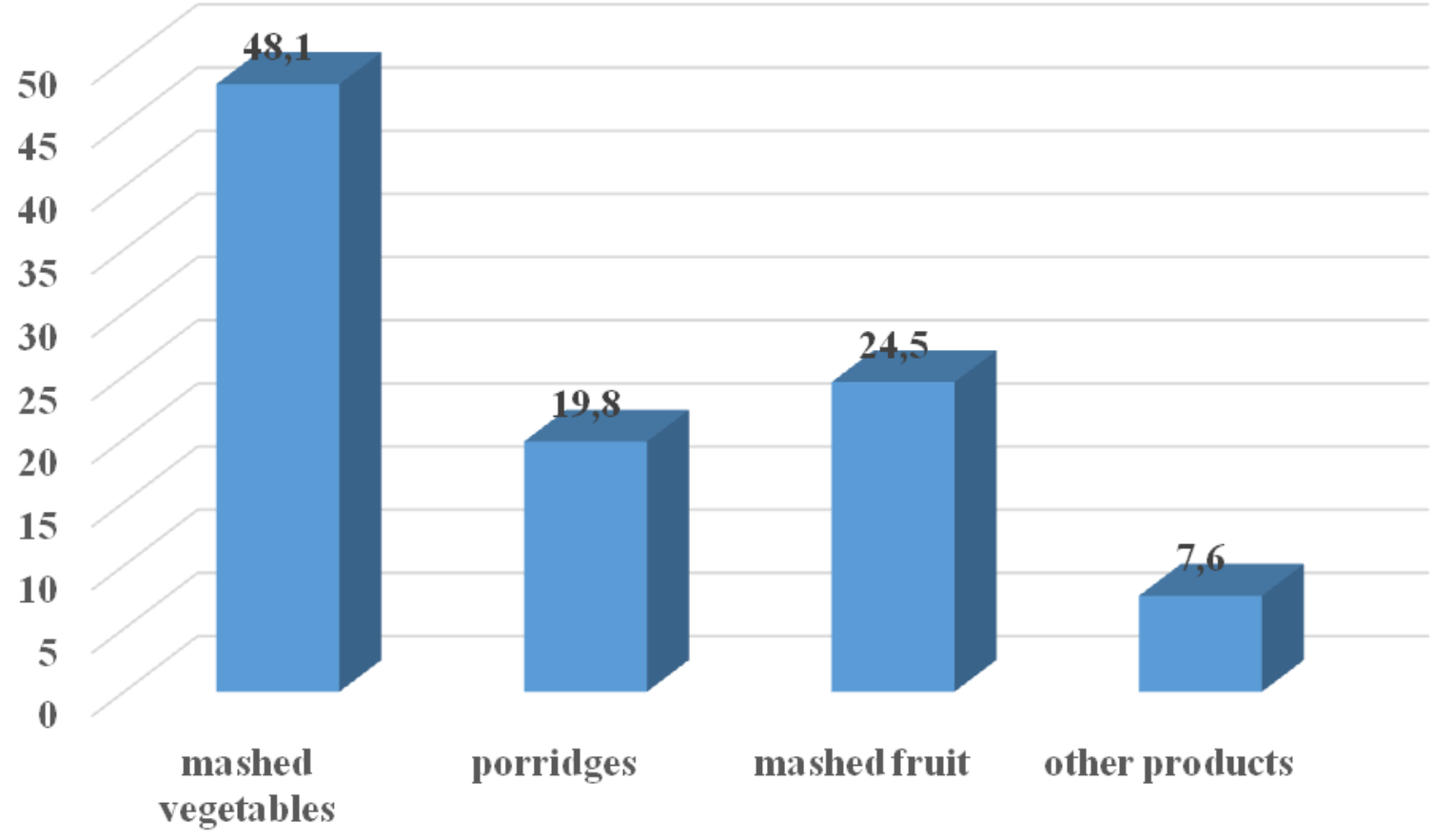

However, it is important to note that, despite the national dietary recommendations, indicating the need to use food products rich in energy, vitamins and minerals, such as industrially produced infant cereals and mashed vegetables as the first supplemental food products, the latter were first introduced in the diets of children only in $67.9 \%$ of cases.

Pic. 5. Average age at introduction of various supplemental food products

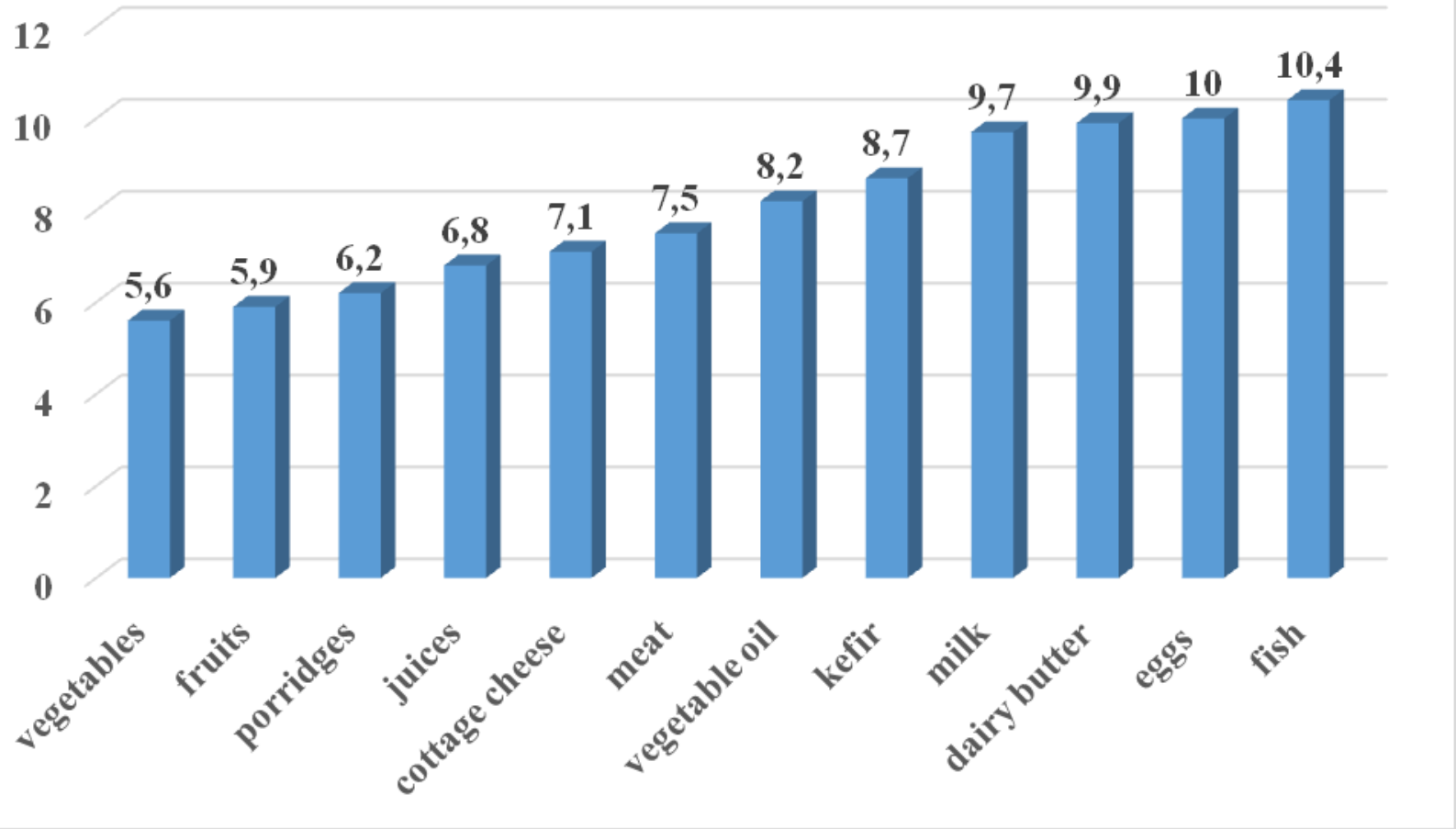


When analyzing the average age at the introduction of various supplemental food products, the following sequence was established: mashed vegetables were introduced at $5.6 \pm 1.5$ months, mashed fruit at $5.9 \pm 1.9$ months, porridge at $6.2 \pm 1.7$ months, fruit juice at $6.8 \pm 3.1$ months, cottage cheese at $7.1 \pm 2.4$ months, mashed meat at $7.5 \pm 1.7$ months, vegetable oil at $8.2 \pm 3.7$ months, kefir at $8.7 \pm 2.4$ months, milk at $9.7 \pm 3.5$ months, butter at $9.9 \pm 3.8$ months, egg yolk at $10 \pm 3.5$ months, mashed fish at $10.4 \pm 3.3$ months (Pic. 5).

The findings suggest that such important products as meat, egg yolk, vegetable oil and fish were introduced into the children's diet much later than recommended [30].

It is important to note that the age of the whole cow milk introduction had a wide scope of 0 to 24 months. The negative effects include the fact that $18.9 \%$ of children began to receive whole cow milk before 3 months of age, and $37.7 \%$ in the age range of 4 to 9 months (Pic. 6).

Pic. 6. Age at introduction of whole cow milk

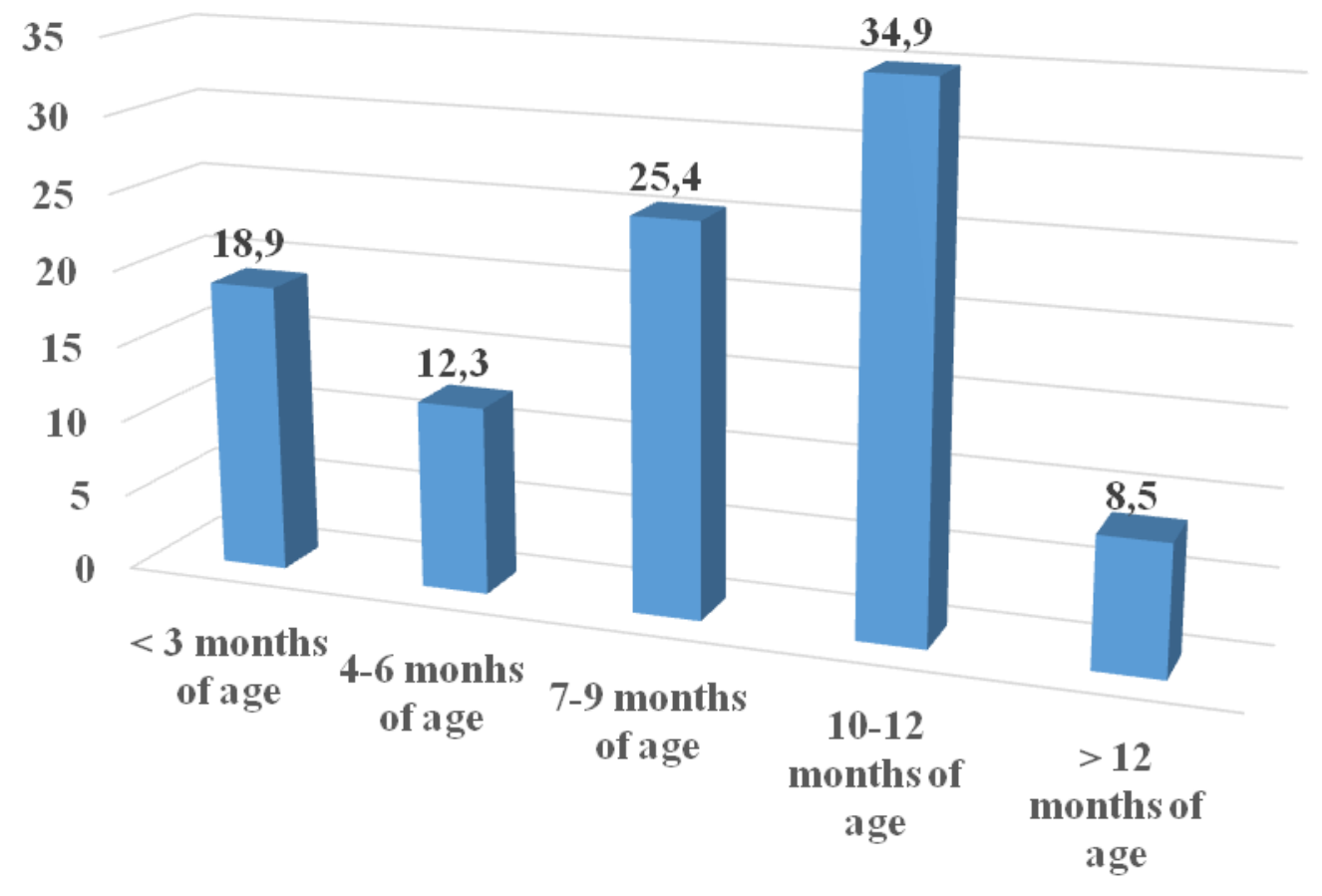

\section{Evaluation of the dietary regimen and the actual nutrition of the children}

The diet regimen analysis found that an overwhelming majority (93 children; 87.7\%) had 4-5 meals a day. Five (4.7\%) of the examined children ( 3 in Group I and 2 in Group II) were fed 3 times a day. It should be noted that only two of the 106 children examined strictly followed the recommended diet. The majority (104 children; 98.1\%) had snacks between meals: 59 (55.6\%) permanently and 45 (42.5\%) periodically. The calculation of daily food consumption showed the following:

- Group I: $1323.7 \pm 37.0 \mathrm{~g}$ :

- boys: $1378.4 \pm 58.9 \mathrm{~g}$;

- girls: $1283.5 \pm 47.0 \mathrm{~g}$;

- Group II: $1496.2 \pm 60.4 \mathrm{~g}$ :

- boys: $1544.2 \pm 93.7 \mathrm{~g}$;

- girls: $1446.1 \pm 76.1 \mathrm{~g}$.

It was found that the daily amount of food in children of both groups slightly exceeded the recommended age nutritional standards. It was noted that the boys consumed more food daily than 
the girls (Table 1). However, the average consumption of juice that was part of the total diet and not perceived as food by the parents is $151.4 \mathrm{ml}$ in the second year and $184.1 \mathrm{ml}$ in the third year of life.

Table 1. The average daily amount of food consumed by the children [31]

\begin{tabular}{|l|l|l|}
\hline Groups of children & $\begin{array}{l}\text { The daily food intake of the } \\
\text { children examined, }\end{array}$ & $\begin{array}{l}\text { The recommended } \\
\text { daily amount* }\end{array}$ \\
\hline $\begin{array}{l}\text { Group I } \\
\text { boys } \\
\text { - girls }\end{array}$ & $1323.7 \pm 37.0$ & $1000-1200$ \\
\hline $\begin{array}{l}\text { Group II } \\
\text { - boys } \\
\text { • girls }\end{array}$ & $1378.4 \pm 58.9$ & \\
\hline
\end{tabular}

Note. * - liquid is not included in the recommended amount

A unified 3-day monitoring of the actual nutrition showed a number of peculiarities in the structure of the examined children's diet.

\section{Milk and dairy products}

Milk and dairy products still played an important role in the infants' nutrition. Almost all the examined children received various dairy products (whole cow milk, fermented milk drinks, cottage cheese and other kinds of cheese). It was found that the average daily amount of dairy products was $442.5 \pm 204.2 \mathrm{ml}$ for the children aged 12-23 months and 455.8 $\pm 268.6 \mathrm{ml}$ for children aged 24-36 months, which is slightly below the recommended age values (Table. 2).

Breast milk in the amount of $411.0 \pm 106.7 \mathrm{ml}$ per day was still received by 35 (33\%) of 106 children in the second year of life, which is consistent with the results of the study by A.K. Baturin et al. (2012). In the third year of life, the daily intake of 150-170 $\mathrm{ml}$ of breast milk was preserved in 1 child's diet.

Table 2. The recommended amount of dairy products for infants [31]

\begin{tabular}{|l|l|}
\hline Products & Quantity (ml, g) \\
\hline Milk & 300 \\
\hline Fermented milk drinks & 200 \\
\hline Cottage cheese & 50 \\
\hline Cheese & $5-10$ \\
\hline
\end{tabular}

It was found that 56 infants (28 in each group; 47.5 and $59.6 \%$, respectively) received whole cow milk at regular intervals (more than 5 times per week). Milk was included irregularly in $10(9.4 \%)$ children's diet, rarely (once a week or less) in $9(8.5 \%)$ of 106 cases. $30(28.3 \%)$ children never received cow milk: 19 in Group I, 11 in Group II.

The analysis of the volume of milk used for nutrition of infants showed that on average, the children of the second year of life received $217.8 \pm 134.7 \mathrm{ml}$, which was equivalent to $72.3 \%$ of the recommended consumption. In the third year of life, these figures were even lower: $185.2 \pm 115.5$ $\mathrm{ml}(61.6 \%$ of the age norm), which is likely due to the expansion of the diet and the introduction of new products. It should be noted that in the majority of cases this amount of milk was used to cook porridge rather than as a beverage.

Milk-based mixtures enriched with nutrients, the so-called infant formulae, designed for children older than 1 year, is rarely used in the nutrition of children of 12-36 months: only $25(42.4 \%)$ children in Group I and $10(21.3 \%)$ in Group II received these products. 
The dairy products in the examined children's diets included cottage cheese, kefir, yogurt, fermented baked milk, curdled milk, and cheese, regularly consumed by $104(98.1 \%)$ children. The number of dairy products in the diet of children in both groups varied widely (from 40 to $950 \mathrm{ml}$ per day) and averaged $256.9 \pm 169.6 \mathrm{ml}(\mathrm{g})$ per day.

At the time of the survey, kefir for children ("Agusha", "Tyoma") was used in the diet of $37(62.7 \%)$ children in Group I and $20(42,6 \%)$ children in Group II in the amount of $163.5 \pm 71.2$ and $210.4 \pm 194.8 \mathrm{ml}$, respectively, which corresponds to the recommended intake for this age.

$20(33.9 \%)$ children in Group I (126.9 $\pm 59.7 \mathrm{ml})$ and $27(57.4 \%)$ in Group II received yogurt for children $(156.7 \pm 80.1 \mathrm{ml})$. The unadapted fermented baked milk, ryazhenka, was rarely used (in 4 children's diets; $3.8 \%$ ).

The age of the introduction of cottage cheese had a wide range from 3 to 24 months. The majority of children in Group I - 79.6\% and 57.4\% in Group II received cottage cheese regularly (over 5 times per week). $6(10.2 \%)$ and $13(27.7 \%)$ children, respectively received cottage cheese one time per week, for $5(8.5 \%)$ and $6(12.8 \%)$ children, respectively, it was even less often. 3.8\% of children (Pic. 7) never received cottage cheese.

Pic. 7. Frequency of consumption of cottage cheese for children

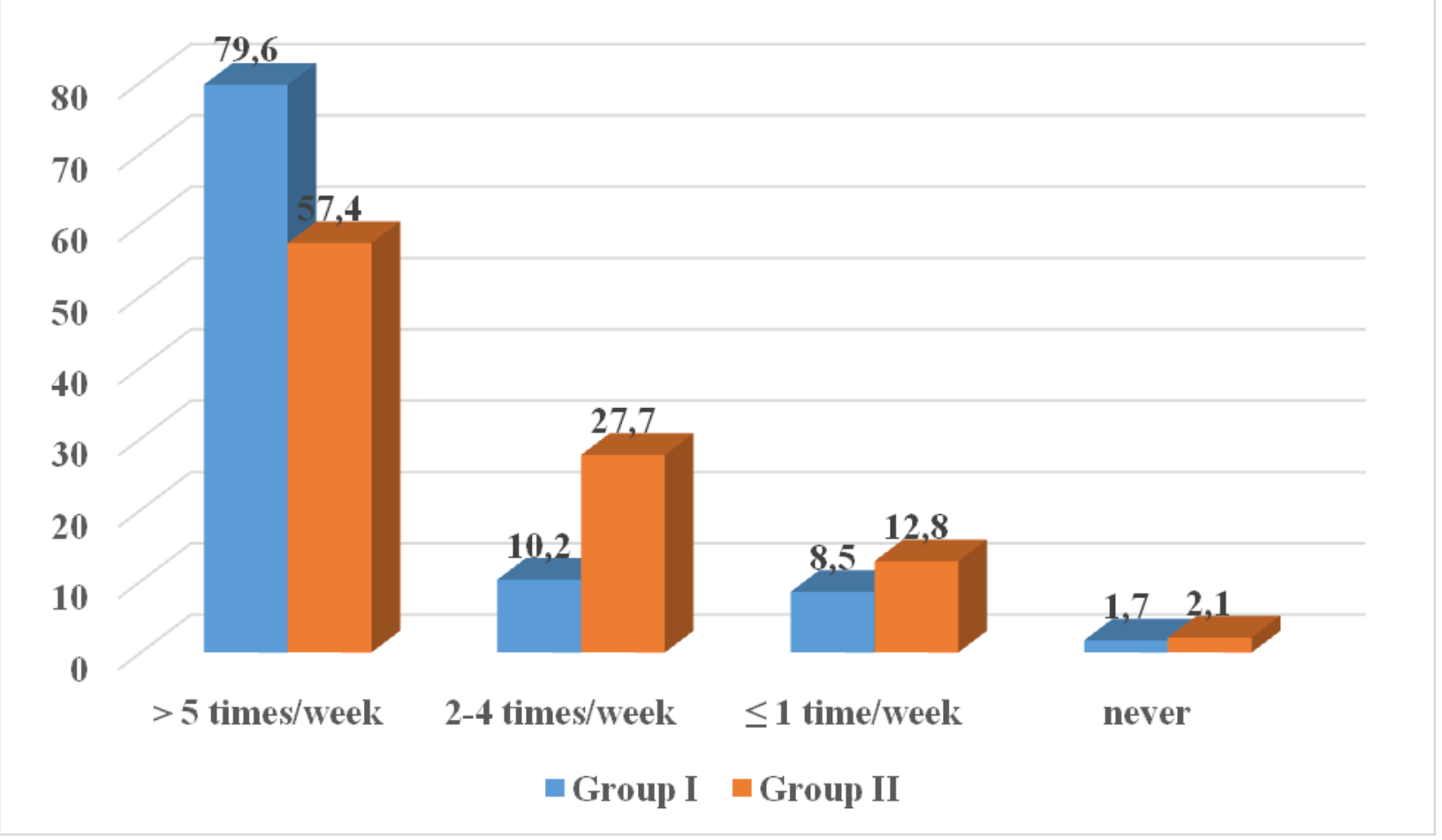

It should be noted that the daily amount of cottage cheese, a product high in protein, averaged $85.6 \pm 38.8 \mathrm{~g}$ in the second year and $97.1 \pm 34.1 \mathrm{~g}$ in the third year, which is $1.5-2$ times higher than the recommended consumption.

Cheese was a part of the diet for 18 (30.5\%) children in Group I and $12(25.5 \%)$ in Group II. The average daily consumption of cheese for infants is 5-10 g/ day. The study found that the daily portion of cheese ranged from 3 to $52 \mathrm{~g}$, averaging $17.5 \pm 12.2$ in Group I and $26.8 \pm 18.1 \mathrm{~g}$ in Group II, which exceeds the recommended age norms 2.3 and 3.6 times, respectively. Cheese is a valuable source of easily digested milk protein and calcium, but it is high in salt, which limits its use in infants' nutrition.

Thus, the results indicate that the structure of the dairy products used in the children's diets varies with age. For example, in the 3rd year of life the intake of cottage cheese and kefir is reduced, and 
yogurt for children is more commonly used. In recent years there has been a trend towards the use of infant formula enriched with nutrients for children older than 1 year. It should be noted that the consumption of the dairy products enriched with nutrients specially intended for this age group, is still low.

\section{Homemade and industrially produced porridge}

Cereal in the form of porridge is present in the diet of the overwhelming majority $(88 ; 83 \%)$ of the children surveyed. $18(17 \%)$ children [9 (15.2\%) in Group I and $9(19.1 \%)$ children in Group II received no cereal.

It was found that $62(70 \%)$ children received specialized enriched infant cereals and muesli, the remaining $26(30 \%)$ had homemade porridge. Porridge was used regularly (up to 4 times a week) in the diet of $46(77.9 \%)$ children in Group I and $27(57.4 \%)$ children in Group II. A rarer use of porridge (at least 4 times per week) was observed in the diets of 4 children (6.8\%) in Group I and 11 (23.4\%) in Group II (Pic. 8).

Pic. 8. Frequency of consumption of supplemental cereal foods (porridges)

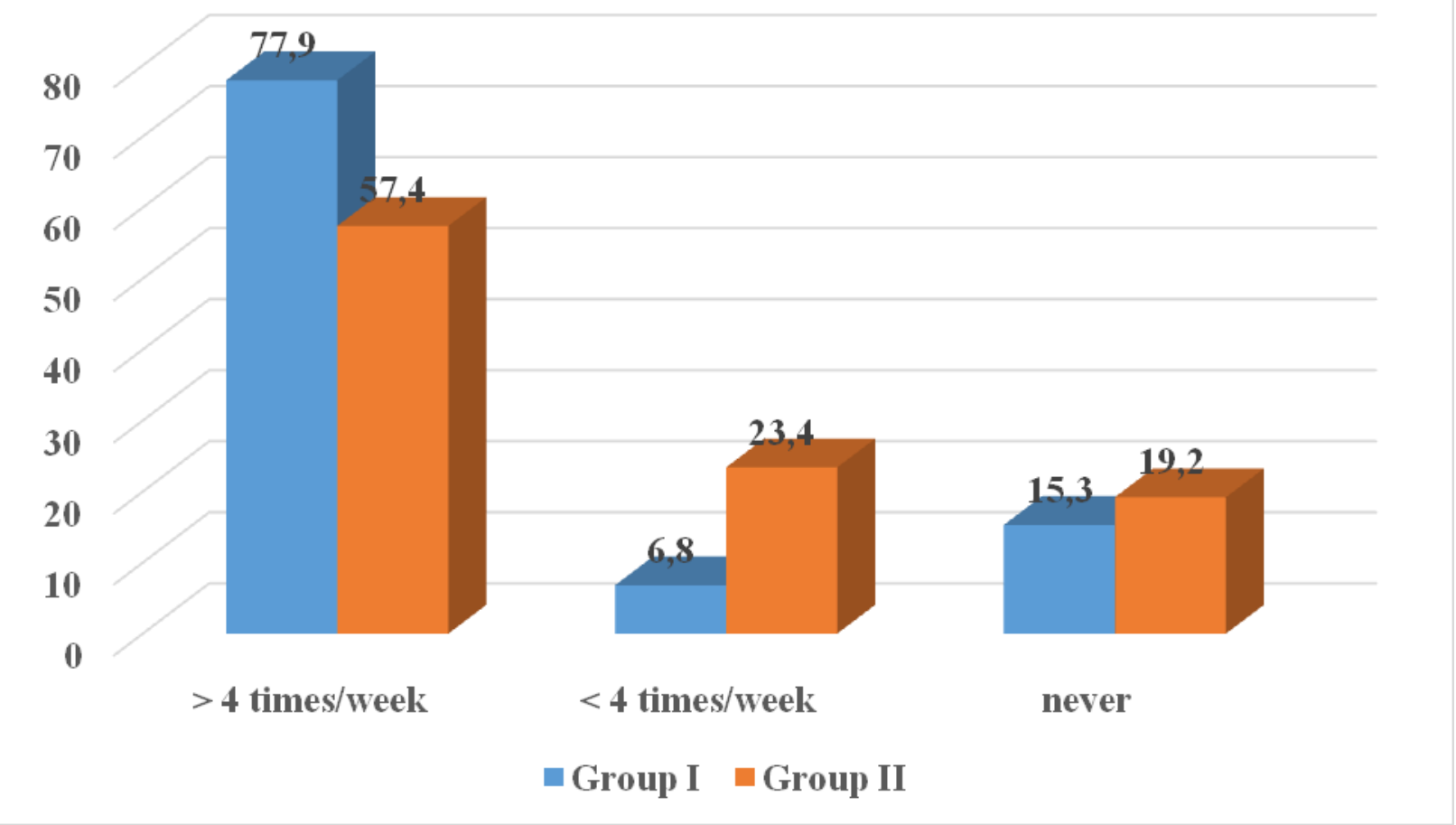

The average daily amount of porridge observed was $181.9 \pm 90.1 \mathrm{~g}$ in the second and $196.0 \pm 70.3 \mathrm{~g}$ in the third year of life, which corresponds to the age recommendations.

The data indicate a rather high consumption of industrially manufactured cereals enriched with a whole complex of micronutrients (vitamins, including group B, minerals, including iron and calcium), as well as the pro- and prebiotics.

\section{Animal-based products: meat, fish, eggs}

Meat products from beef, pork, chicken, turkey and other meats are used in a variety of cooked dishes (meat gaucher, mashed meat, finely chopped boiled meat, faggots, meatballs, patty cakes, etc.). They were regularly ( 5 or more times a week) consumed by the majority of children in both groups: $45(76.2 \%)$ and $45(95.7 \%)$, respectively. $7(11.9 \%)$ children in Group I and $2(4,3 \%)$ 
children in Group II received meat less often, no more than 3-4 times per week; and 7 (11.9\%) children in Group I (Pic. 9) ate meat rarely (1-2 times per week).

Pic. 9. Frequency of consumption of animal-based dishes

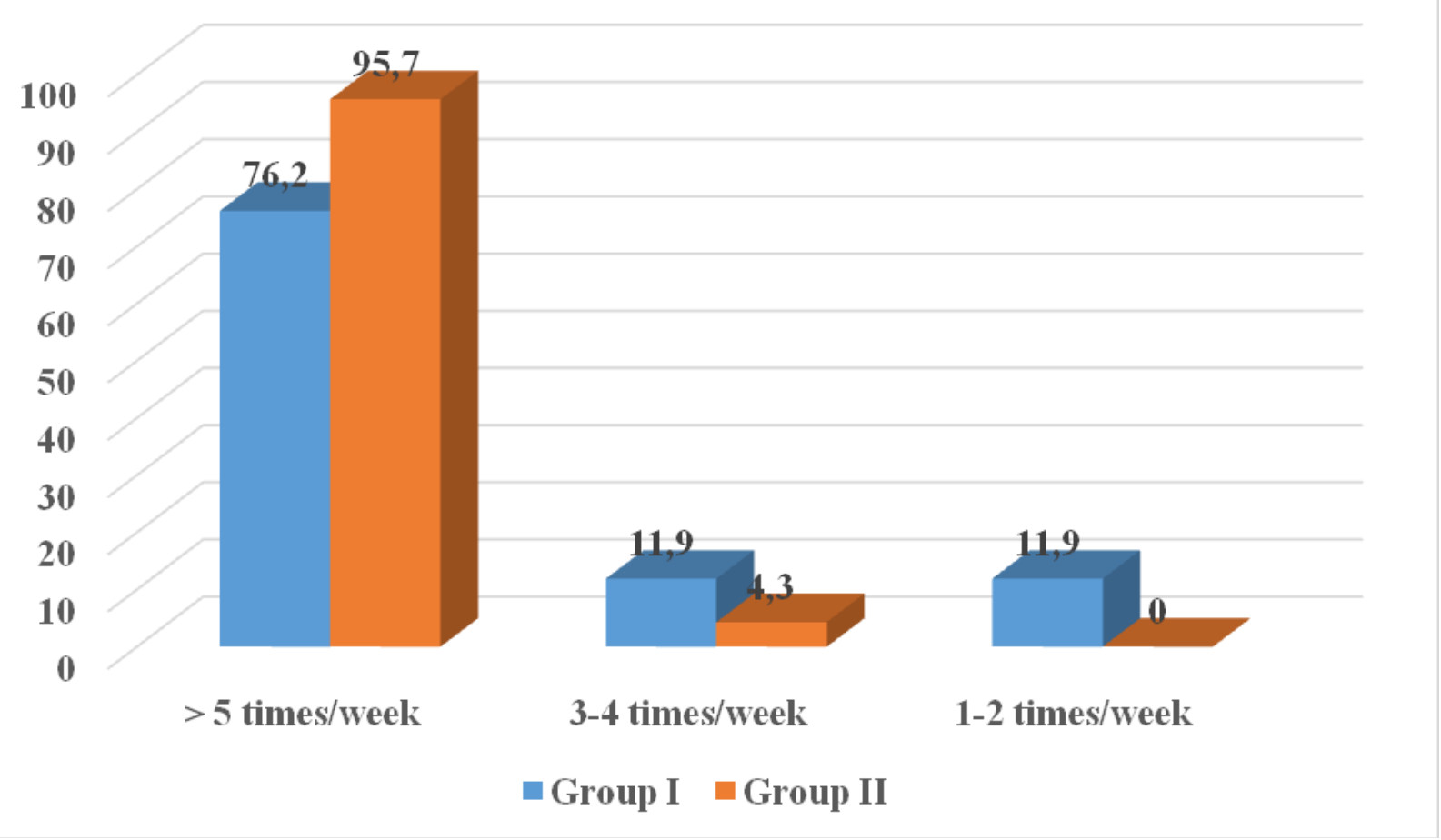

It should be noted that such an important product as fish, the main source of $\omega$ - 3 long-chain polyunsaturated fatty acids is not used in the diet of all the surveyed children: in Group I, it is $52(88.1 \%)$, children, in Group II - 45 (95. 7\%) children.

Fish was regularly (1-3 and more times per week) consumed by most of the children in both groups: $40(67.8 \%)$ and 32 (68.1\%), respectively; rarely (less than once per week) consumed by $12(20.3 \%)$ and $13(27.7 \%)$ children, respectively. Only two children (one child from each group) received fish more than 4 times per week. 16.2\% of the children in both groups (Pic. 10) never ate fish.

Pic. 10. Frequency of consumption of fish-based dishes 


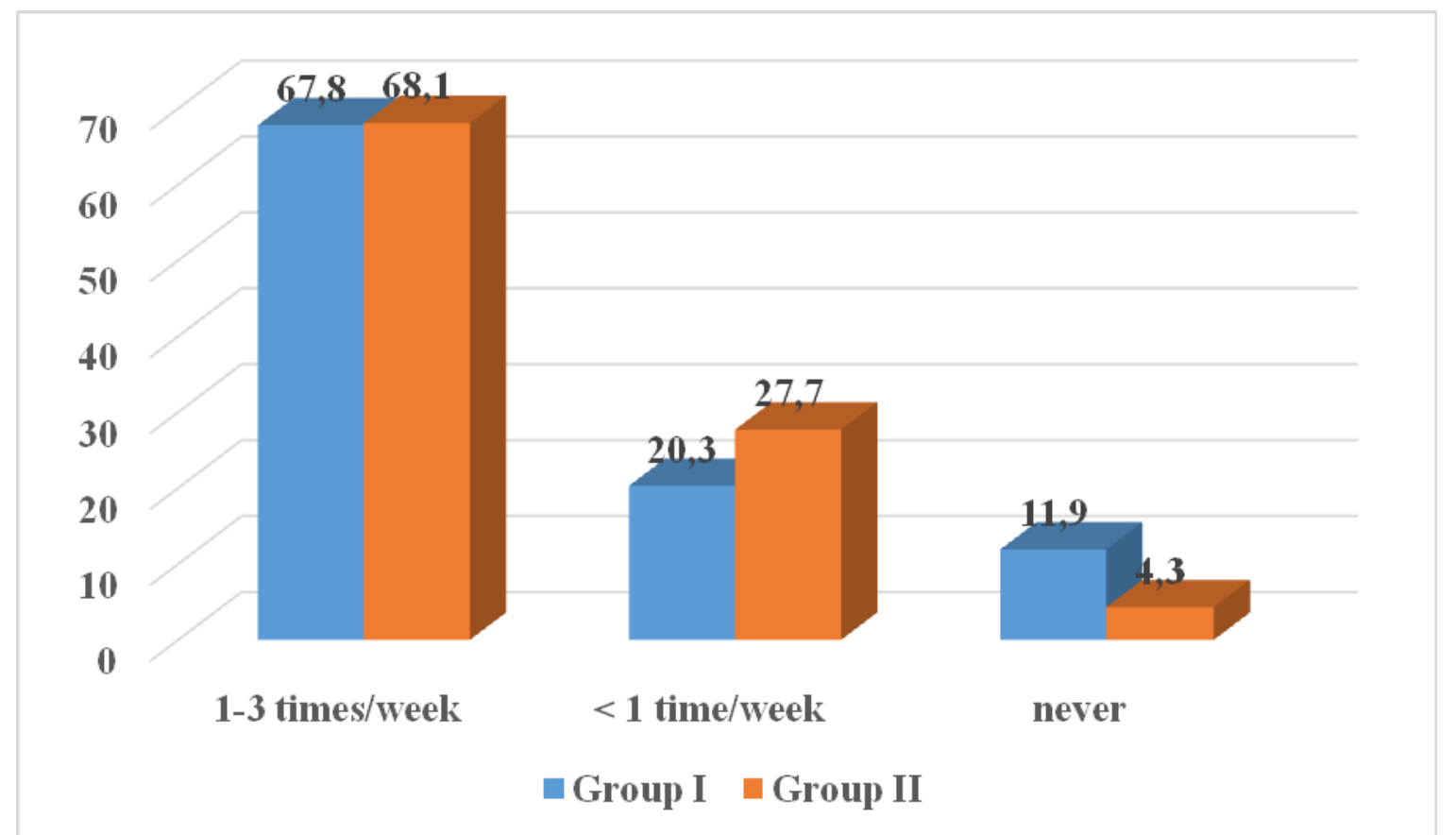

Overall, the findings suggest a fairly wide consumption of fish dishes young children in accordance with current dietary recommendations. The absence of fish in the diet of some children may be due to the child refusing the product as well as the food preferences of the family.

Egg yolk was introduced into the nutrition of children aged 4 to 24 months (averaging $10.02 \pm 3.5$ months). Egg dishes were regularly (more than 3 times per week) consumed by 16 children $(27,1 \%)$ in Group I and $22(46,8 \%)$ children in Group II; $1-3$ times per week by $29(49.2 \%)$ children in Group I and 17 (36.2\%) children in Group II, rarely (less than once per week) by 10 $(16.9 \%)$ and $6(12.8 \%)$ children, respectively. 6 children $(5.6 \%)$ never ate eggs.

\section{Vegetables and fruit}

Almost all children included in the study (99\%) consumed fruit in the form of fresh and mashed fruit. Regular (at least 5 times a week) consumption of fruit was observed in $52(88.1 \%)$ and 41 $(87.2 \%)$ children in Groups I and II, respectively. Relatively rare (less than 5 times a week) was the presence of fruit in the diet of $6(10.2 \%)$ children of the second year and $6(12.8 \%)$ children of the third year. 1 child of Group I refused to eat any fruit (Pic. 11).

Pic. 11. Frequency of fruit consumption 


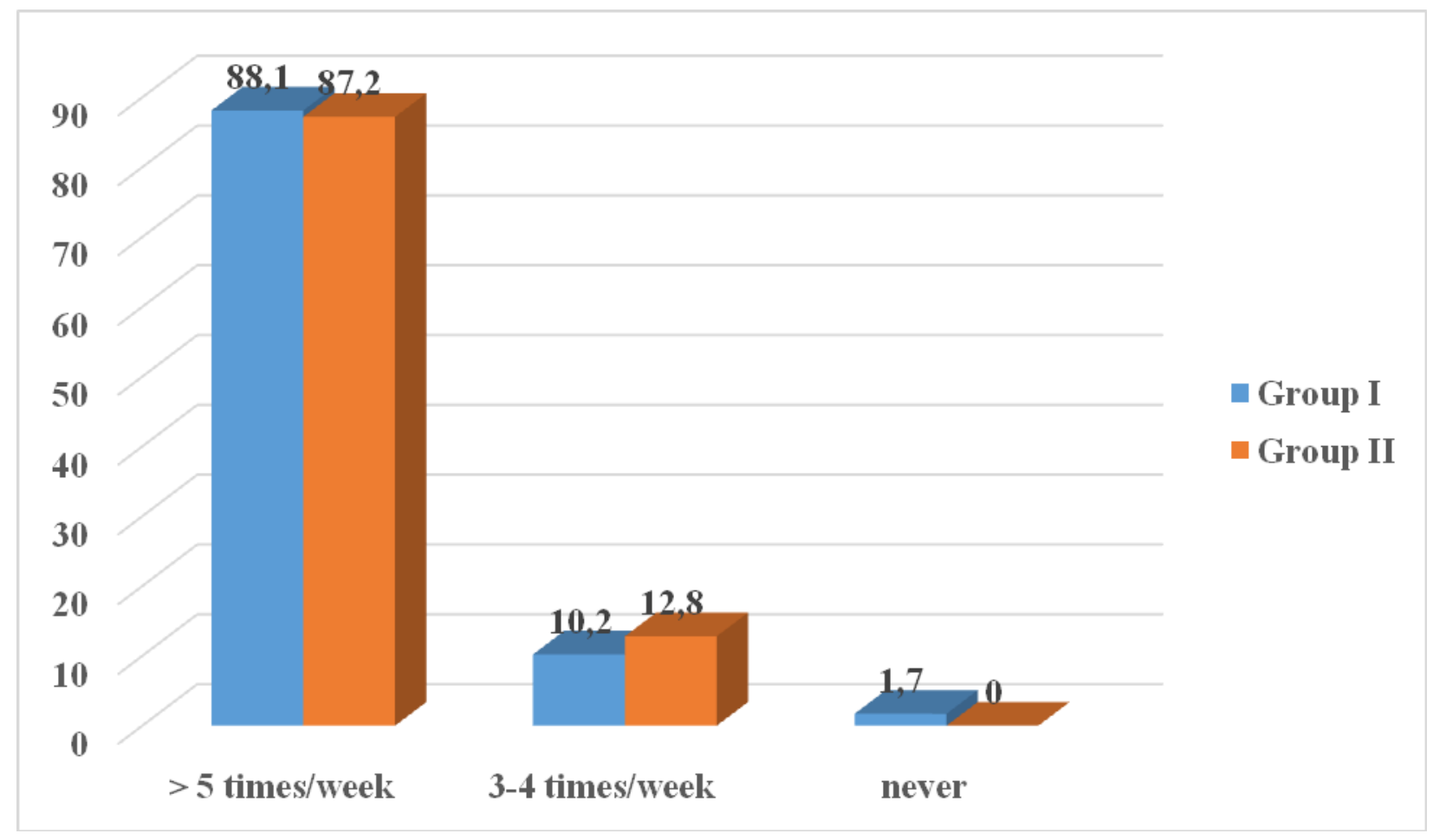

The analysis of fruit and vegetable juice consumption has shown that the age of their introduction ranged from 2 to 15 months and the quantity varied in the wide range of 20 to $500 \mathrm{ml}$ per day. Juices have a relatively low nutritional value, and due to the high content of organic acids their excessive consumption has a stimulating effect on the digestive system, and a large amount of sugar present in juices poses a risk of tooth decay and obesity.

According to the currently effective regulations, the recommended daily amount of juice for children of 1-3 years is $150 \mathrm{ml}$ [31].

On average, children in Group I received $133.3 \pm 65.7 \mathrm{ml}$ and in Group II $190.5 \pm 108.3 \mathrm{ml}$ of juice per day. When analyzing the amount of the product it was found that $17.5 \%$ of children in both groups received a small $(20-50 \mathrm{ml})$ amount of juice, $69.8 \%$ received an excess amount $(200 \mathrm{ml}$ or more), and only in $12.7 \%$ the intake corresponded to the norm.

In Group I, juices were given regularly (more than 5 times a week) to $33(55.9 \%)$ children, less frequently (2-4 times per week) to $11(18.7 \%)$ children, very rarely (once per week or less) to 10 $(16.9 \%)$. 5 children (8.5\%) never received juice. In group II, these figures were $26(55.3 \%)$, $11(23.4 \%), 7(14.9 \%)$ and $3(6.4 \%)$ children, respectively.

According to the study, vegetables in general were present in the diet of all the children.

Vegetables were regularly ( 5 times or more per week) used in the nutrition of $43(72.9 \%)$ children in Group I and 31 (65.9\%) children in Group II; 3-4 times per week in the nutrition of $11(18.6 \%)$ and $12(25.6 \%)$ children; rarely (1-2 times per week) in the diets of 3 children in each group (5.1 and $6.4 \%$, respectively); very rarely (at least once per week) in the diets of $2(3.4 \%)$ and $1(2.1 \%)$ children, respectively (Pic. 12).

Pic. 12. Frequency of consumption of vegetable dishes 


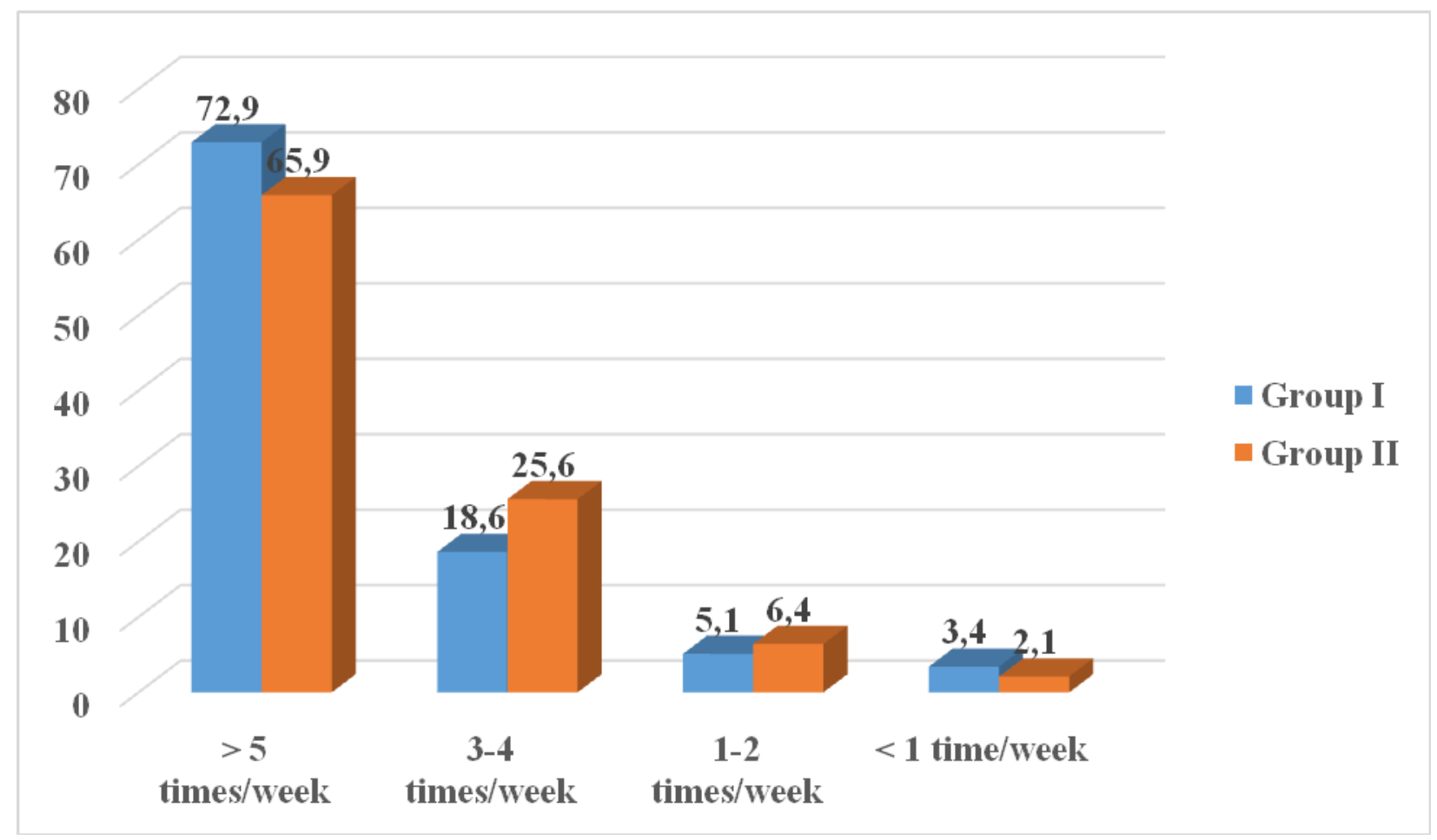

Thus, the diets of the majority of the surveyed infants included the required amounts of all the basic food products: milk and its derivatives, including the infant formula; cereals, including industrially produced and enriched with micronutrients; fruit and vegetables, meat and fish. However, our attention is drawn to the inadequate intake of specialized infant formula enriched cereals in the diet of the children older than 1 year that allow reducing the existing deficit of vitamins and micro- and macronutrients. In addition, an excessive consumption of cottage cheese and juice by some children is revealed.

\section{Peculiarities of the diet and nutritional habits formation}

The data obtained from the study showed that the number of children receiving food of the general (family) table increases with age. However, in more than a half (56 families; 52.8\%) families, the mothers continued to cook specially for the children - in $27(45.8 \%)$ families in Group I and $29(61.7 \%)$ families in Group II. Food products adapted for children, rich in macro- and micronutrients (cereal, milk formula for children older than 1 year, mashed fruit and others) were present in the diet of $50(47.2 \%)$ of the 106 children surveyed: $32(54.2 \%)$ in Group I and 18 $(38.3 \%)$ in Group II.

The analysis of the actual food intake showed that "adult" products [seafood, ketchup, mayonnaise, ready-to-cook foods (pizza, ravioli), chips, sausages, chocolate, sodas] were given to children in both groups. It should be emphasized that the amount of these products increased significantly as the children grew (Table 3).

Table 3. Frequency of "adult" food consumption, $\%$

\begin{tabular}{|l|l|l|l|}
\hline \multirow{2}{*}{ Products } & Groups & $\begin{array}{l}\text { Repetition factor between the } \\
\text { groups }\end{array}$ \\
\cline { 2 - 4 } & $\begin{array}{l}\text { Group I } \\
\mathbf{1 2 - 2 4} \text { months }\end{array}$ & $\begin{array}{l}\text { Group II } \\
\mathbf{2 4 - 3 6} \text { months }\end{array}$ & \\
\hline Chips, rusks, snacks & 6.8 & 23.3 & 3.4 \\
\hline Seafood & 27,1 & 46,8 & 1.7 \\
\hline Ketchup & 5,1 & 23.4 & 4.5 \\
\hline Mayonnaise & 3.4 & 29.8 & 8.7 \\
\hline
\end{tabular}




\begin{tabular}{|l|l|l|l|}
\hline Sausages & 30.6 & 87.2 & 2.8 \\
\hline $\begin{array}{l}\text { Ready-to-cook products (meat dumplings, } \\
\text { pizza, etc.) }\end{array}$ & 23.7 & 68.1 & 2.8 \\
\hline Chocolate & 32.2 & 80.9 & 2.5 \\
\hline Sodas & 1.7 & 4.2 & 2.4 \\
\hline
\end{tabular}

Analysis of the development of eating habits found that more than $1 / 3$ of the children surveyed $(35.7 \%)$ received salted foods, and $32.9 \%$ received added sugar.

Confectionery products such as sweets (jelly, marshmallow, jam, candy, etc.) and pastry (cookies, waffles, cakes, etc.), as well as bread and bakery products (muffins, bagels, etc.) were present in the diet of $30(50.9 \%)$ children of the second year of life and $42(89.4 \%)$ children of the third.

\section{Evaluation of the nutritional value of the diet}

In assessing the actual food intake by counting the chemical composition of daily rations it was found that the consumption of basic macronutrients in the children of Groups I and II was as follows:

- proteins: $47.8 \pm 12.3$ and $56.3 \pm 18.0 \mathrm{~g}$ per day (substantially exceeding the average aged-matched intake by 32.7 and $34.0 \%$, respectively);

- fats: $48.8 \pm 11.7$ and $54.9 \pm 14.8 \mathrm{~g}$ per day (exceeding the average aged-matched intake by 22.0 and $16.8 \%$, respectively);

- carbohydrates: $162.0 \pm 31.9$ and $194.4 \pm 40.6$ g per day (slightly exceeding the average agedmatched intake within the permissible variation by 6.9 and $4.4 \%$, respectively).

However, the energy value of the daily nutrition was close to the recommended: 1297 and $1502 \mathrm{kcal}$ in Groups I and II, respectively (Table 4).

Table 4. Chemical composition and energy value of the average daily rations of children aged from 12 to 36 months (in comparison with the age-average physiological needs) [31]

\begin{tabular}{|c|c|c|c|c|c|c|c|c|c|c|c|c|}
\hline \multirow{3}{*}{$\begin{array}{l}\text { Groups } \\
\text { of } \\
\text { children }\end{array}$} & \multicolumn{9}{|c|}{ Ingredients, $\mathrm{g}$} & \multirow{2}{*}{\multicolumn{2}{|c|}{$\begin{array}{l}\text { Energy value, } \\
\text { kcal }\end{array}$}} & \multirow{3}{*}{$\begin{array}{l}\text { Recommended } \\
\text { energy value, } \\
\text { kcal }^{1}\end{array}$} \\
\hline & \multicolumn{2}{|c|}{ Proteins } & \multirow{2}{*}{$\begin{array}{l}\text { Recommended } \\
\text { protein intake }{ }^{1}\end{array}$} & \multicolumn{2}{|l|}{ Fat } & \multirow{2}{*}{$\begin{array}{l}\text { Recommended } \\
\text { fat intake }^{1}\end{array}$} & \multicolumn{2}{|c|}{ Carbohydrates } & \multirow{2}{*}{$\begin{array}{l}\text { Recommended } \\
\text { carbohydrate } \\
\text { intake }^{1}\end{array}$} & & & \\
\hline & $\mathbf{M}^{*}$ & $S D^{* *}$ & & $M^{*}$ & $S D^{* *}$ & & $\mathbf{M}^{*}$ & $S D^{* *}$ & & $\mathbf{M}^{*}$ & $S^{* *}$ & \\
\hline I & 47.8 & 12.3 & 36 & 48.8 & 11.7 & 40 & 162.0 & 31.9 & 174 & 1297 & 207.4 & 1200 \\
\hline II & 56.3 & 18.0 & 42 & 54.9 & 14.8 & 47 & 194.4 & 40.6 & 203 & 1502 & 299.5 & 1400 \\
\hline
\end{tabular}

Note. ${ }^{1}$ The average physiological needs for energy and nutrients established for different groups of the population of Russian Federation, MP 2.3.1.2432-08, approved by the top sanitary official of Russia, G.G. Onishchenko, on December 18, 2008. M: mean, SD: standard deviation.

According to the data presented in Table 4, the daily protein, fat and carbohydrate intake ratio in the groups examined was $1: 1: 3.4$ and $1: 1: 3.5$, while the recommended ratio is $1: 1: 4$.

According to the recommendations of the Research Institute of Nutrition experts, the daily energy consumption of infants should be provided by $12-14 \%$ of proteins, $25-35 \%$ of fats and $55-60 \%$ of carbohydrates [30]. Evaluating the main nutrients' contribution to the overall calorie intake, it was established that the proportion of proteins in the daily energy intake was $15.1 \%$ in both groups, which is slightly higher than the recommended physiological norm (on the average, by 1.1-3.1\%); fat provided $33.9 \%$ of the energy for the children in Group I and 32.9\% - in Group II, which corresponds to the current recommendations. At the same time, the amount of carbohydrates in providing the total daily calorie intake in both groups was reduced to 51.0 and $52.0 \%$, respectively, which is below the recommended quantities by 4-9 and 3-8\%, respectively (Table 5).

Table 5. The proportion of the basic nutrients in providing the calorie intake of children aged from 12 to 36 months 


\begin{tabular}{|l|l|l|l|}
\hline & Proteins & Fats & Carbohydrates \\
\hline I & 15.1 & 33.9 & 51.0 \\
\hline II & 15.1 & 32.9 & 52.0 \\
\hline Recommended values & & & \\
& $12-14$ & $25-35$ & $55-60$ \\
\hline
\end{tabular}

\section{DISCUSSION}

Adequate nutrition is the basis of the health for children of all age groups. It is of the greatest importance at an early age, which is a period of active formation of all organs and systems of the child's body. The modern recommendations for first year infants' nutrition are discussed in detail in The National Program for optimization of infants' nutrition in the first year of life, approved at the $\mathrm{XVI}^{\text {th }}$ Congress of Pediatricians of Russia in 2009. Similar national guidelines the on nutrition of children aged 1 to 3 years are still missing.

Given the importance of a balanced diet and its influence on the formation of all the functions and structures of the body, as well as preserving health at the later age, epidemiological observational studies are required that allow a comprehensive assessment of the character and peculiarities of the diet of children aged 1 to 3 years. In Russia there have been only few such studies, which is why this epidemiological study was carried out; its purpose was to assess the characteristics of nutrition of children aged 12-36 months living in Moscow.

The analysis of medical history data revealed that almost all the children came from socially advantaged families, and more than a half of the families had a history of allergic diseases. All the observed children were breastfed during the first year of life, the average length of breastfeeding was $8.9 \pm 6.8$ months. In this case, there was an increasing trend in terms of the duration of breastfeeding: $1 / 3$ of the children continued to be breastfed in the second year of life.

In general, the diet of children 12-36 months contained sufficient quantities of all the basic food products: milk and its derivatives; cereals, including industrially produced cereals enriched with nutrients; fruit and vegetables, meat and fish. This study revealed excessive consumption of highprotein dairy products by some of the children: cottage cheese, by 1.5 times in the second and by 2 times in the third year of life; cheese, by 2.3 and 3.6 times, respectively, as well as juices, the volume of which in some cases reached $500 \mathrm{ml}$ per day.

Milk-based mixtures enriched with nutrients, the so-called infant formulae, designed for children older than 1 year, were only given to $42.4 \%$ of children of $1-2$ years and $21.3 \%$ of the children of 2 3 years, while having a balanced composition, containing the optimal amounts of vitamins and minerals, enriched with beneficial nutritional factors (pre- and probiotics, long chain polyunsaturated fatty acids, nucleotides). The infant formulae are becoming increasingly common in the diet of infants as they may compensate the micronutrient deficiency often observed at this age and are essentially functional foods that have a positive effect on the child's health.

The diet of the majority consisted of 4-5 meals, while the average amount of food consumed was $1323.7 \pm 37$ and $1496.2 \pm 60.4 \mathrm{~g}$ in the second and third year, respectively, which is slightly higher than recommended by the modern nutritional standards. In most cases (98\%) the dietary regimen was disturbed by frequent snacking between meals, which is known to lead to a decrease in appetite, exclusion of important products and dishes from the child's diet, and contribute to obesity. Noteworthy is the presence of excessive protein (32 and 34\%) and fat (22 and 16.8\%) in the diet of children of the second and third year, respectively, while maintaining, however, the physiological age norm energy value of food and closeness to the recommended major nutrients ratio.

A gradual transfer of homemade dishes to the children's diet and increasing the frequency of meat and fish product consumption is observed.

Unfortunately, at the same time increase in consumption of "adult" food like sausages (reaching up to $87.2 \%$ by 3 years of age), ready-to-cook products (meat dumplings, pizza), chocolate, seafood, 
etc. is observed, which has an adverse effect on the taste habits and eating behavior, condition of the gastrointestinal tract, contribute to the development of vitamin and mineral deficit, and leads to an excessive intake of saturated fats. Subsequently, these factors can cause the development of excess weight and obesity, as well as chronic diseases of the digestive system.

\section{CONCLUSION}

Thus, as the result of the epidemiological observational study on the characteristics of the actual nutrition of healthy children aged 12-36 months living in Moscow, it was revealed that most of them regularly received the foods considered basic for this period of life. However, there is excessive consumption of high-protein dairy products like cottage cheese and other kinds of cheese, as well as inadequate use of specialized products: infant formulae for children over 1 year of age and cereals enriched with micronutrients. Attention is drawn to the frequent violation of the dietary regimen of children, inadequate consumption of industrially produced "adult" products (ravioli, pizza, sausages, seafood, sauces, chips, sweets, sodas) that have an adverse effect on the child's eating behavior, metabolism, state of digestive system etc.

Analysis of the nutritional value showed that, given a sufficient calorie intake in both groups of the examined children, the intake of protein exceeded the physiological age limit consumption by a factor of 1.3, and of fat by a factor of 1.2. These diet violations may contribute to excessive weight gain and the development of metabolic abnormalities that require further research. In order to preserve the balance of macro- and micronutrients, the intake of modern functional foods enriched with nutrients on the dairy, grain and other basis in the infants' diet should be increased.

\section{CONFLICT OF INTEREST}

The study was financially supported by "Nutricia", LLC.

\section{REFERENCES}

1. Anemiya u detei: diagnostika, differentsial'naya diagnostika i lechenie. Prakticheskoe posobie dlya vrachei pod red. A.G. Rumyantseva, Yu.N. Tokarevoi. 2-e izd., dop. i pererab. [Anemia in children: diagnosis, differential diagnosis and treatment. Guidelines for Physicians. Edited by A.G. Rumyantsev, Yu.N. Tokareva. 2nd edition, revised and enlarged]. Moscow, MAKS Press, 2004. 216 p.

2. $\quad$ Borovik T.E., Ladodo K.S. Klinicheskaya dietologiya detskogo vozrasta. Rukovodstvo dlya vrachei [Clinical Dietetics childhood. Guidelines for Physicians]. Moscow, Meditsinskoe informatsionnoe agentstvo, 2008. $608 \mathrm{p}$.

3. Iron deficiency anemia: assessment, prevention and control. A guide for programmer managers. Geneva: World Health Organization. 2001 (document WHO/NHD/01/3).

4. Grantham-McGregor S., Ani C. The role of micronutrients in psychomotor and cognitive development. Br Med Bull. 1999; 55: 511-527.

5. Sharapova O.V., Dedov I.I., Korsunskii A.A. et al. Iodine Deficiency Disorders in Children in the Russian Federation. Voprosy sovremennoi pediatrii = Current Pediatrics. 2004; 3: 8-14.

6. Carlson S.E., Neuringer M. Polyunsaturated fatty acids status and neurodevelopment a summary and critical analysis of the literature. Lipids. 1999; 34: 171-178.

7. Spirichev V.B. The role of vitamins and minerals in bone formation and preventing children osteopathy. Voprosy detskoi dietologii = Problems of child nutrition. 2003; 1 (1): 40-49.

8. Benton D. ILSI Eruope f.i.s.b.l. Micronutrient status, cognition and behavioral problems in childhood. Eur J Nutr. 2008 Aug; 47 (Suppl. 3): 38-50.

9. Baturin A.K., Netrebenko O.K. The practice of feeding children during the first two years of life in Russia. Pediatriya = Pediatrics. 2010; 90 (3): 99-110. 
10. Fantino M., Gourmet E. Nutrient intakes in France in 2005 by non-breast fed children of less than 36 months. Archives de Pediatrie. 2008; 15: 446-455.

11. Eriksson J.E. Early adiposity rebound in children hood and risk of Type 2 diabetes in adult life. Diabetologia. 2003; 46: 190-194.

12. Barker D. Growth and living condition in childhood and hypertension in adult life: a longitudinal study. J Hypertens. 2002; 20: 1951-6.

13. Lucas A. Role a nutritional programming in determining adult morbidity. Arch Dis Child. 1994; 71: 288-290.

14. Netrebenko O.K., Borovik T.E., Skvortsova V.A. Eating disorders in young children.

Lechashchii vrach $=$ The attending physician. $2011 ; 1: 36-41$.

15. Hurley K.M., Cross M.B., Hughes S.O. A systematic review of responsive feeding and child obesity in high-income countries. Journal of Nutrition. 2011; 141: 495-501.

16. Koletzko B., von Kries R., Monasterolo R. Lower protein in infant formula is associated with lower weight up to age 2 y: a randomized clinical trial. Am J Clin Nutr. 2009; 89: 1-10.

17. Baturin A.K., Ogloblin N.A., Volkova L.Yu. The results of the study of calcium intake of children in the Russian Federation. Voprosy detskoi dietologii = Problems of child nutrition. 2004; 2: $7-10$.

18. Tutel'yan V.A., Baturin A.K., Kon' I.Ya., Keshabyants E.E., Starovoitov M.L., Safronova A.M., Gmoshinskaya M.V. Nature of malnutrition in infants and young children in the Russian Federation: the practice of introduction of complementary foods. Pediatriya $=$ Pediatrics. 2009; 88 (6): 77-83.

19. Birch L., Fisher J. Development of eating behaviors among children and adolescents. Pediatrics. 2010; 101: 539-549.

20. Ladodo K.S. Ratsional'noe pitanie detei rannego vozrasta [monografiya] [Rational Nnutrition of Young Children [Monograph]]. Moscow, Miklosh, 2007. 280 p.

21. Baranov A.A., Kuchma V.R., Sukhareva L.M. Otsenka zdorov'ya detei i podrostkov pri profilakticheskikh meditsinskikh osmotrakh. Rukovodstvo dlya vrachei [Assessment of Health of Children and Adolescents with Preventive Medical Examinations. Guidelines for Pediatricians]. Moscow, Izdatel'skii Dom «Dinastiya», 2004. 168 p.

22. Profilakticheskaya pediatriya. Rukovodstvo dlya vrachei. Pod red. A.A. Baranova [Preventive Pediatrics. Guidelines for Pediatricians. Ed. by A.A. Baranov]. Moscow, Soyuz pediatrov Rossii, 2012. $692 \mathrm{p}$.

23. Baturin A.K., Keshabyants E.E., Safronova A.M., Netrebenko O.K. Programming Meal Plan: children older than one year. Pediatriya = Pediatrics. 2013; 92 (2): 91-99.

24. Surzhik A.V., Borovik T.E., Zakharova I.N., Namazova-Baranova L.S., Skvortsova V.A., Lukoyanova O.L, Zvonkova N.G. Results of an epidemiological study nature and characteristics of nutritional status of children aged 12-36 months in the Russian Federation. Part I. Voprosy sovremennoi pediatrii $=$ Current Pediatrics. 2013; 12 (1): 30-36.

25. Produkty pitaniya dlya detei rannego vozrasta. Katalog pod red. T.E. Borovik, K.S. Ladodo, V.A. Skvortsovoi [Food for infants. Catalog edited by T.E. Borovik, K.S. Ladodo, V.A. Skvortsova]. Moscow, 2011. 480 p.

26. Spetsializirovannye produkty pitaniya dlya detei s razlichnoi patologiei. Katalog pod red. T.E. Borovik, K.S. Ladodo, V.A. Skvortsovoi [Specialized Food for Children with Different Pathologies. Catalog edited by T.E. Borovik, K.S. Ladodo, V.A. Skvortsova]. Moscow, 2012. 184 p. 27. Khimicheskii sostav i energeticheskaya tsennost' pishchevykh produktov. 6-e izd.

Spravochnik pod red. Makkansa i Uidsona. Per. s angl. [Chemical Composition and Energy Content of Foodstuffs. 6th ed. Handbook edited by McCance and Widson. Translated from English]. St.

Petersburg, Professiya, 2006. 416 p. 
28. Tekhnologicheskaya instruktsiya po proizvodstvu kulinarnoi produktsii dlya pitaniya detei $i$ podrostkov shkol'nogo vozrasta v organizovannykh kollektivakh. Moskovskii fond sodeistviya sanitarno-epidemiologicheskomu blagopoluchiyu naseleniya [Technological Instructions for the Production of Culinary Products for Babies and Early School-age Children in Organized Groups. Moscow Fund to Promote Sanitary and Epidemiological Welfare of the Population]. Moscow, 2006. 29. Natsional'naya programma po optimizatsii vskarmlivaniya detei pervogo goda zhizni $v$ Rossiiskoi Federatsii [The National Program to Optimize Feeding Infants in the Russian Federation]. Moscow, Soyuz pediatrov Rossii, 2009. 67 p.

30. Pitanie zdorovogo i bol'nogo rebenka. Pod red. V.A. Tutel'yana, I.Ya. Konya, B.S. Kaganova. Izd. 7-e [Feeding a Healthy and Sick Child. Edited by V.A. Tutel'yan, I.Ya. Kon', B.S. Kaganov]. Moscow, Izdatel'stvo «Dinastiya», 2013. 264 p.

31. Normy fiziologicheskikh potrebnostei v energii i pishchevykh veshchestvakh dlya razlichnykh grupp naseleniya Rossiiskoi Federatsii, MR 2.3.1.2432 -08, utverzhdeny Glavnym sanitarnym vrachom RF G.G. Onishchenko 18.12.2008 [Standards of Physiological Needs for Energy and Nutrients for Different Groups of Population of the Russian Federation, MR 2.3.1.2432 -08, approved by the Chief Sanitary Doctor of Russia G.G. Onishchenko dated 18.12.2008]. 